\title{
Resensie: Teologie van die koninkryk. Studies in dogmatiek en etiek
}

\begin{tabular}{|c|c|}
\hline \multicolumn{2}{|c|}{$\begin{array}{l}\text { Teologie van die koninkryk. } \\
\text { Studies in dogmatiek en etiek }\end{array}$} \\
\hline \multicolumn{2}{|l|}{ Book Cover: } \\
\hline \multicolumn{2}{|c|}{ 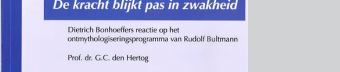 } \\
\hline \multicolumn{2}{|c|}{ 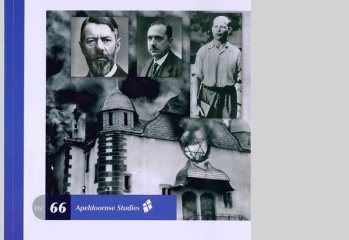 } \\
\hline \multicolumn{2}{|l|}{$\begin{array}{l}\text { Author: } \\
\text { J.H. van Wyk }\end{array}$} \\
\hline \multicolumn{2}{|c|}{$\begin{array}{l}\text { ISBN: } \\
978-0-620-66210-9\end{array}$} \\
\hline $\begin{array}{l}\text { Publisher: } \\
\text { V\&R Drukker } \\
\text { *Book price at } \\
\text { Unknown }\end{array}$ & $\begin{array}{l}2015, \\
\text { me of review }\end{array}$ \\
\hline \multicolumn{2}{|c|}{$\begin{array}{l}\text { Reviewer: } \\
\text { Nico Vorster }\end{array}$} \\
\hline \multicolumn{2}{|c|}{$\begin{array}{l}{ }^{1} \text { Faculty of Theology, } \\
\text { North-West University, } \\
\text { Potchefstroom Campus, } \\
\text { South Africa }\end{array}$} \\
\hline \multicolumn{2}{|c|}{$\begin{array}{l}\text { Corresponding author: } \\
\text { Nico Vorster, } \\
\text { nico.vorster@nwu.ac.za }\end{array}$} \\
\hline \multicolumn{2}{|c|}{$\begin{array}{l}\text { How to cite this book review: } \\
\text { Vorster, N., 2016, 'Resensie: } \\
\text { Teologie van die koninkryk. } \\
\text { Studies in dogmatiek en } \\
\text { etiek', In die Skriflig 50(1), } \\
\text { a2144. http://dx.doi. } \\
\text { org/10.4102/ids.v50i1.2144 }\end{array}$} \\
\hline \multicolumn{2}{|c|}{$\begin{array}{l}\text { Copyright: } \\
\text { (c) 2016. The Authors. } \\
\text { Licensee: AOSIS. This work is } \\
\text { licensed under the Creative } \\
\text { Commons Attribution License. }\end{array}$} \\
\hline \multicolumn{2}{|l|}{ Read online: } \\
\hline 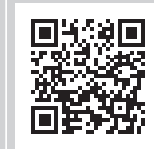 & $\begin{array}{l}\text { Scan this QR } \\
\text { code with your } \\
\text { smart phone or } \\
\text { mobile device } \\
\text { to read online. }\end{array}$ \\
\hline
\end{tabular}

Hierdie publikasie van prof. Amie van Wyk bevat 'n reeks artikels in die dogmatiek en etiek wat hy oor 'n periode van 30 jaar geskryf het. Sommige daarvan is in Afrikaans, ander in Engels en een in Duits geskryf. Die samebindende tema van die boek is die koninkryk van God wat Van Wyk deur sy loopbaan as 'n organiserende beginsel in sy teologie gebruik het.

Die artikels is onder ' $n$ verskeidenheid groter temas gesorteer wat op die openbaringsleer, skeppingsleer, ekklesiologie, etiek en eskatologie betrekking het.

Hoewel die boek in hooftemas ingedeel is, is die formaat daarvan ' $n$ belangrike tekortkoming. Teologie van die koninkryk. Studies in dogmatiek en etiek bevat 'n wye verskeidenheid van artikels in verskillende tale oor uiteenlopende onderwerpe. Dit kan waarskynlik die impak van die boek negatief beïnvloed.

Die eerste deel van die publikasie handel oor die Woord en die openbaring van God. Na die artikel wat handel oor die historiese ontwikkeling van Skrifverklaring, tree Van Wyk in gesprek met verskeie Suid-Afrikaanse teoloë soos M.A. Kruger, Dirkie Smit, Gert Malan en Gerrie Snyman oor hermeneutiese vrae. Hoewel die aanpak hiervan soms baie oorsigtelik is, spreek dit oor die algemeen van'n gebalanseerde benadering tot die Skrifleer. Van Wyk probeer om'n gereformeerde Skrifleer te handhaaf sonder om in uiterstes soos fundamentalisme te verval.

Die tweede groep artikels handel oor God en sy skepping. Die eerste artikel in hierdie afdeling handel oor die Christelike verstaan van God se drie-eenheid in vergelyking met die Godskonsep van die tradisionele Afrika-godsdienste. Met die tweede artikel tree Van Wyk in gesprek met Armando Pellecin se ateïstiese standpunte; die derde artikel handel oor evolusie en in die laaste bydrae onder hierdie tema tree Van Wyk in gesprek met Adrio König se voorsienigheidsleer. 'n Vraag wat miskien aan Van Wyk gestel kan word, is waarom daar in gesprek getree is met 'n betreklik onbekende ateïs soos Pellecin en nie met meer invloedryke ateïste soos Slavoj Zizek nie. Die kwaliteit van bespreking in hierdie groep artikels is egter deurlopend goed, die aanpak daarvan interessant en die opinies wat uitgespreek word is insiggewend. Van Wyk bied rigtinggewende voorstelle vir die kerklike hantering van vraagstukke soos evolusie waarvan kerke deeglik kennis behoort te neem.

In die derde deel van die boek tree Van Wyk in gesprek met Sakkie Spangenberg na aanleiding van sy boek getiteld Jesus van Nasaret (2009). Van Wyk bespreek die filosofiese vooronderstellings wat Spangenberg se standpunt onderlê en vra dan 'n reeks kritiese vrae aan hom. Van Wyk se konklusie is dat Spangenberg se teologie op Jesuilogie neerkom wat die voorbeeld van Jesus as mens aanhang, maar dat sy benadering nie as Christelike teologie getipeer kan word nie omdat hy Jesus se middelaarskap, opstanding en verheerliking ontken.

Die vierde afdeling van die boek met 13 artikels handel oor die Heilige Gees, koninkryk en kerk. Van Wyk besin in hierdie afdeling oor die verhouding tussen die verbond en koninkryk, kerklike eenheid en die sakramente asook kerk-staat verhoudings. In hierdie afdeling kom Van Wyk se eskatologies-teologiese benadering die sterkste na vore. Die koninkryk is vir Van Wyk nie bloot een bybelse tema te midde van ander nie, maar die samebindende tema wat aan die hele Christelike teologie inhoud gee. Die koninkryk van God relativeer en relateer alle aardse gesag en werk transformerend op sosiale strukture in. Hierdie reeks artikels toon teologiese diepgang; verskillende moderne en klassieke teoloë se standpunte word met insig en nuanse bespreek; en die teologiese gevolgtrekkings volg logies uit die bespreking.

Die vyfde afdeling handel oor die kerk, teologie en apologetiek. Van Wyk tree in hierdie afdeling met André P. Brink, die Nuwe Hervorming en Alan Boesak in gesprek. Die diskussie met Brink is veral besonder interessant en bied aan teoloë sowel as letterkundiges navorsingswaardige inligting oor Brink se lewe en denkwyse. 
Die laaste twee afdelings handel onderskeidelik oor die Christelike lewe en die eskatologie. In die afdeling getiteld 'Etiek, spiritualiteit en die Christelike lewe' bespreek Van Wyk die Christelik-etiese bydraes van Augustinus, Calvyn en Barth asook dié van Johan Heyns. In die afdeling oor die eskatologie word Calvyn se verstaan van die koninkryk en die eskatologiese implikasies daarvan bespreek. Die laaste artikel sou moontlik beter gepas het in die afdeling oor kerk en koninkryk. Nieteenstaande is die besprekings telkens interessant en prikkelend.

Teologie van die Koninkryk. Studies in Dogmatiek en Etiek is 'n indrukwekkende boek deur een van die mees gerespekteerde gereformeerde teoloë wat Suid-Afrika nog opgelewer het. Ten spyte van die tekortkomings in die formaat, kan hierdie boek met vrymoedigheid aanbeveel word vir teoloë sowel as studente. Die leser word gekonfronteer met 'n magdom perspektiewe van klassieke en moderne teoloë wat op sigself reeds 'n goeie oriëntasie vir die leser gee. Die artikels word deurgaans gekenmerk deur 'n helder teologiese gedagtegang, goeie organisering van materiaal, welbelesendheid en insiggewende perspektiewe. Die styl is deurlopend genuanseerd en gebalanseerd. Die belangrikste bydrae van die boek is, myns insiens, die rigtinggewende standpunte wat in nederigheid gestel word nadat verskeie ander benaderings bespreek is. Predikante sal heelwat preekstof in die boek vind, terwyl teoloë nie alleen die besprekings sal geniet nie, maar ook die oriëntasies in die ontwikkeling van historiese teologiese denklyne sal waardeer. 